\title{
Quantifying sediment discharge from the Bolivian Andes into the Beni foreland basin from cosmogenic ${ }^{10} \mathrm{Be}$-derived denudation rates
}

\author{
Hella Wittmann ${ }^{1,2}$, Friedhelm von Blanckenburg ${ }^{1,2}$, Jean-Loup Guyot ${ }^{3}$, \\ Laurence Maurice ${ }^{4}$ \& Peter Kubik ${ }^{5}$
}

\begin{abstract}
Enormous volumes of sediment are produced in the Central Andes and are then delivered into the foreland basins of Amazon basin tributaries. While cosmogenic nuclides in sediment are a suitable tool to measure the denudation rates of sediment-producing areas, the requirement of steady state between nuclide production and nuclide removal by denudation appears to make this method less obvious in depositional foreland basins, where sediment storage may alter ${ }^{10} \mathrm{Be}$-based erosion signals from the sediment-providing areas. A published cosmogenic nuclide-based modeling approach however predicts that source-area cosmogenic nuclide concentrations are not modified by temporary sediment storage. We tested this approach in the large Beni foreland basin by measuring cosmogenic ${ }^{10} \mathrm{Be}$ nuclide concentrations in detrital sediment along a $600 \mathrm{~km}$ long floodplain reach. The outcome of our study is that the ${ }^{10} \mathrm{Be}$-based denudation rate signal of the Bolivian Andes is preserved in the Beni floodplain even though this basin stores the sediment for thousands of years. For the floodplain part of the Beni basin, the cosmogenic nuclide-derived denudation rate is $0.45 \pm 0.07 \mathrm{~mm} / \mathrm{yr}$, and the respective Andean source area erodes at a very similar rate of $0.37 \pm 0.06 \mathrm{~mm} / \mathrm{yr}$. We thus suggest that any sample collected along a river traversing a floodplain will yield the denudation rate of the source area. This finding opens the unique possibility of constraining paleo-sediment budgets for these large basins using cosmogenic nuclides as the denudation rate signal of the sediment-producing area is preserved in sedimentary archives.
\end{abstract}

Keywords: Denudation, Erosion, Sediment delivery, Cosmogenic nuclides, Cosmogenic ${ }^{10}$ Be, Bolivian Andes, Beni River, Madeira River.

Resumo Quantificação da descarga sedimentar na bacia de Beni (Andes bolivianos) por meio da taxa de denudação obtida por isótopos cosmogênicos de ${ }^{10} \mathrm{Be}$. O grande volume de sedimento produzido pelas bacias foreland dos Andes Centrais é carregado pelos tributários da bacia do rio Amazonas. Embora os cosmonuclídeos em sedimento constituam uma ferramenta atraente para estimativa da taxa de denudação de áreas-fonte, a exigência da relação inicial entre a produção e a remoção de nuclídeos torna o método menos óbvio no caso de bacias foreland, nas quais o estoque de sedimento pode alterar os sinais de erosão pelo ${ }^{10}$ Be das áreas-fonte. Um modelo de nuclídeos cosmogênicos já publicado afirma contudo que a concentração dos nuclídeos não é modificada pelo estoque temporário de sedimento. No presente trabalho esse modelo foi testado na grande bacia foreland de Beni pela medição das concentrações de nuclídeos de ${ }^{10} \mathrm{Be}$ em sedimento detrítico de um trecho de $600 \mathrm{~km}$ ao longo da planície de inundação do rio Beni. Os resultados revelaram que o sinal da taxa de denudação baseada em de nuclídeos de ${ }^{10} \mathrm{Be}$ é preservado nos depósitos da planície de inundação do rio Beni, mesmo em setores onde os sedimentos estejam estocados por milhares de anos. Os valores da taxa de denudação por ${ }^{10} \mathrm{Be}$ encontrados na planície de inundação e na área fonte foram bastante semelhantes: $0,45 \pm$ 0,07 e $0,37 \pm 0,06 \mathrm{~mm} /$ ano respectivamente. Dessa forma sugere-se que qualquer amostra coletada ao longo de tributários que atravessem a planície de inundação fornecerá a taxa de erosão da área fonte. Esse resultado antevê a possibilidade de uma redução expressiva na amostragem em estudos que objetivem o cálculo da taxa de denudação baseada em cosmonuclídeos.

Palavras-chave: Denudação; Erosão; Fornecimento de sedimento, Cosmonuclídeos, ${ }^{10} \mathrm{Be} \operatorname{cosmogênico,~Andes~}$ bolivianos, Rio Beni, Rio Madeira.

INTRODUCTION Cosmogenic nuclides in detrital material, especially ${ }^{10}$ Beryllium (Be), have been used over the past decade to determine catchment-wide mountain erosion and weathering rates (Bierman
\& Nichols 2004, Granger \& Riebe 2007, von Blanckenburg 2005). It has been found over recent years that even in very complex settings like formerly glaciated basins, cosmogenic nuclides mostly record

1 - Institut für Mineralogie, Universität Hannover, Hannover, Alemanha. E-mail: wittmann@gfz-potsdam.de, fvb@gfz-potsdam.de

2 - GeoForschungszentrum Potsdam, Telegrafenberg, Potsdam, Alemanha.

3 - Institut de Recherche pour le Développement - IRD, Brasília (DF), Brasil. E-mail: jean-loup.guyot@ird.fr

4 - Laboratoire des Mécanismes de Transfert en Géologie - LMTG, IRD/CNRS - Université de Toulouse, Toulouse, França. E-mail: laurence.maurice@ird.fr

5 - Laboratory of Ion Beam Physics, ETH Zurich, Zurich, Suíça. E-mail: kubik@phys.ethz.ch 
robust basin-wide denudation rates when compared to long-term denudation meters measured by fission tracks (Kirchner et al. 2001, Matmon et al. 2003, Wittmann et al. 2007). In this study, we will test whether this method can be used to infer basin-wide denudation rates from sediment routed through large depositional settings (Bierman \& Steig 1996, Nichols et al. 2005, Nichols et al. 2002). In such basins, sediment is continuously deposited in the floodplain and reincorporated in the active fluvial system by bank erosion. This transient residence in the floodplain with unknown duration may affect cosmogenic nuclide concentrations in such way that the nuclide concentration that is inherited from the erosion process in the source area may severely be modified by exposure to cosmic rays in the floodplain or during deep floodplain burial. Wittmann \& von Blanckenburg (2009) predicted that despite significant floodplain storage, the denudation signal of the sediment-producing hinterland (e.g. the Bolivian Andes) that is preserved in ${ }^{10} \mathrm{Be}$-nuclide concentrations is not changed over foreland-basin scale distances by using a nuclide budgeting approach. The essentially pristine floodplains of the upper Amazon basin are an ideal setting to test this hypothesis. The cosmogenic nuclide signal of the high Bolivian Andes is well established by a large dataset from Safran et al. (2005). For this area, fission track-derived long-term rates of erosion are also available (Safran et al. 2006). For the $\sim 600 \mathrm{~km}$ long Beni floodplain, an average residence time for sediment is $\sim 5 \mathrm{kyr}$ as measured from U-series by Dosseto et al. (2006). We will show here that it is indeed possible to calculate meaningful catchmentwide denudation rates for the hinterland in large depositional basins, and we do so by providing new cosmogenic nuclide concentrations from Beni River floodplain sediment.

\section{GEOLOGY, GEOMORPHOLOGY AND}

CLIMATE One major Amazon foreland basin to the Andean orogenic belt is the Madeira basin, which comprises the Beni $\left(\sim 300,000 \mathrm{~km}^{2}\right)$ and the adjacent Mamoré basin $\left(\sim 600,000 \mathrm{~km}^{2} ;\right.$ Fig. 1). With an annual discharge exceeding $32,000 \mathrm{~m}^{3} / \mathrm{s}$ at its confluence with the Amazon, and an average suspended sediment load of $>400 \mathrm{Mt} / \mathrm{yr}$ (Wittmann et al. 2011), the Madeira ranks the fourth to fifth largest river in the world (Latrubesse 2008, Latrubesse et al. 2005) and thus is one of the largest sediment-delivering rivers to the Amazon River (Guyot et al. 1996). In the Madeira basin upstream of Porto Velho (Fig. 1), three major morpho-structural units are present: The Bolivian segment of the Andes at average elevations of $\sim 2,000 \mathrm{~m}$, the Amazon plain featuring vast flooded areas at altitudes $<200 \mathrm{~m}$; and the subdued topography of the Brazilian shield featuring elevations of $\sim 400 \mathrm{~m}$, constituting old Precambrian rocks (outcropping only in lower Mamoré areas). The transition of the sediment-producing Andean areas to the depositional floodplain setting is located at the city of Rurrenabaque; downstream in the floodplain part to the confluence with the Mamore River at Cachuela Esperanza (Fig. 1), the Beni River has two large tributaries, the Madre de Dios River at Miraflores draining the Peruvian and Bolivian Andes, and the Orthón River, a tributary exclusively draining Miocene lowland sediments of the Fitzcarrald Arch formation (Espurt et al. 2007). Beni River channel migration rates average at $\sim 15 \mathrm{~m} / \mathrm{yr}$ (Aalto 2002a), with meander-bend migration rates up to $\sim 30 \mathrm{~m} / \mathrm{yr}$ (Gautier et al. 2007), accounting for rapid sediment exchange between the floodplain and the mainstream. Regarding the floodplain setting of the Beni, Plafker (1964) was the first one to point out that the Beni River channel experienced successive counterclockwise shifts from SE to NW. The river course evidently adjusted to basinal uplift located in the area south of Puerto Siles, with remnant structures (i.e. underfit streams, oxbow lakes) still present in the area east of the modern channel (see Dumont 1996, for details). Simultaneously to the counterclockwise shifting, Dumont (1996) suggested that the deflection point (i.e. the point where the Beni River leaves the piedmont and enters the floodplain) shifted northward, potentially resulting in changes in Andean drainage area upstream of the floodplain. The timing of these changes has not been pinned down with modern dating techniques and only indirect methods are available; for example, Dumont (1996) correlates remnant channel structures of the two earliest shifts to periods of lower discharge than today and thus these channels may represent the active Beni River during last Holocene dry phase (Dumont 1996). Various paleoclimatic evidence from the Central Andes suggests that the mid-Holocene ( $\sim 8$ to $\sim 5-4 \mathrm{kyr}$ before present, "B.P.") underwent a major phase of aridity with very low rates of precipitation (e.g. Cross et al. 2000, Rowe et al. 2002, Tapia et al. 2003). This emplacement to the mid-Holocene period enables a very tentative time frame for the shift of the paleo-Beni River following the interpretation of Dumont (1996). Within the remaining Holocene period until today, the Central Andes probably experienced a wetter climate similar to today's (Abbott et al. 2003, Tapia et al. 2003).

\section{METHODS}

Cosmogenic nuclide sampling and analytical techniques Our cosmogenic nuclide sampling of sediment from active fluvial bars was carried out near a gauging monitoring station where possible (Fig. 1). All samples were collected by J.L. Guyot within the framework of the HYBAM project. The upper Andean Beni basin is characterized by sample Be 1 at Rurrenabaque. In the Beni floodplain, our sampling transect covers a distance across the floodplain of about $600 \mathrm{~km}$ from Rurrenabaque to Cachuela Esperanza (samples Be 2 to 17). Tributary input to the Beni is characterized by samples from the rivers Madre de Dios at Miraflores (Md 15), and the Orthón at Caracoles (Or 16). The lower Mamoré floodplain was sampled at Guayaramerin (Mar 18). The latter sample integrates over the cratonic areas of the Brazilian Shield $(\sim 50 \%$ 


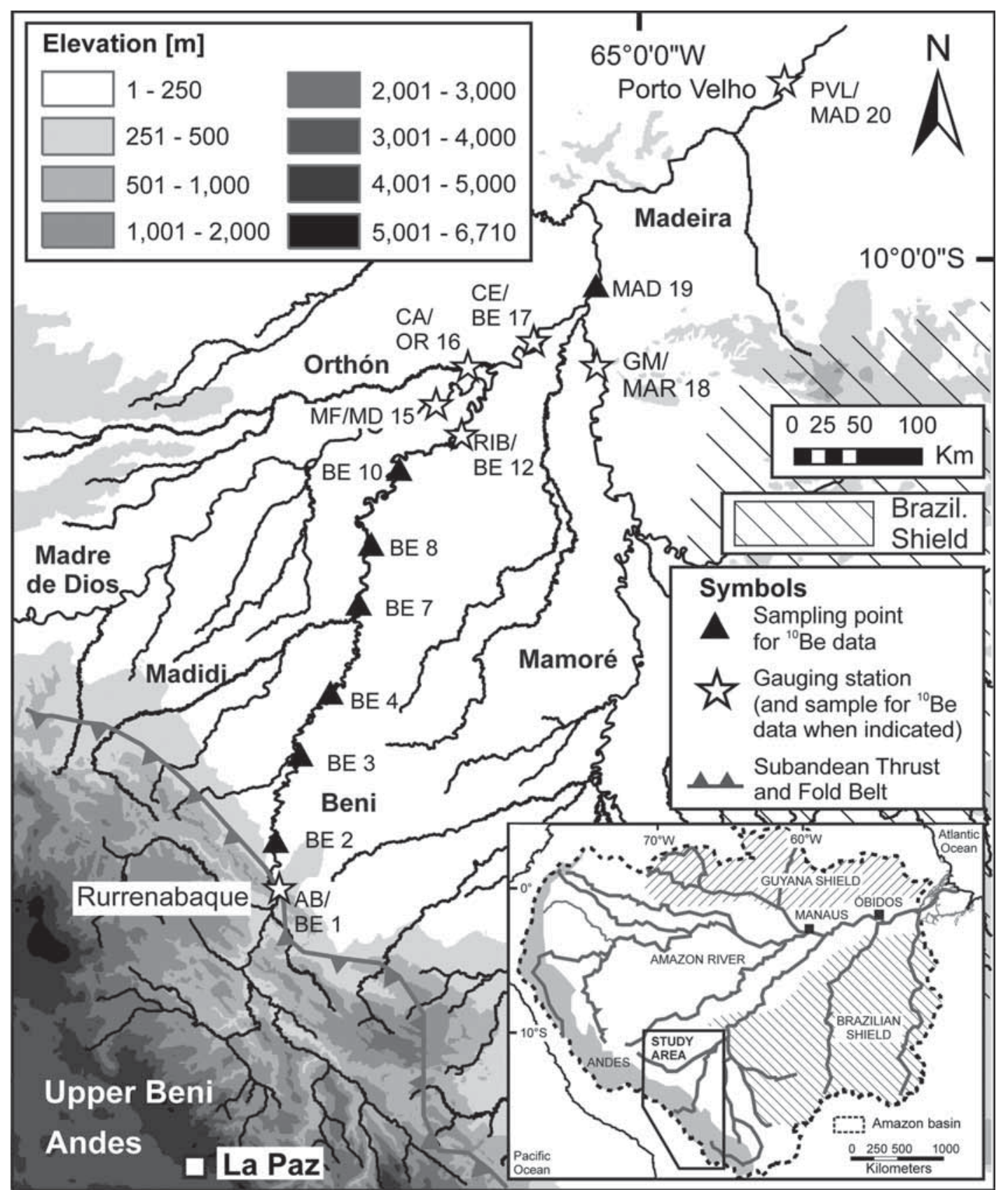

Figure 1 - Detailed topographic map and fluvial network of the Beni River basin with sampling points for cosmogenic ${ }^{10}$ Be (black triangles). Sediment gauging stations (white stars) operated by HYBAM are abbreviated as in Guyot et al. (1996). Where cosmogenic samples were taken at the same location as a gauging station, the sample name is indicated below the HYBAM gauging station code.

floodplain area; $\sim 60 \%$ Brazilian Shield area; $\sim 10 \%$ Andean territory). The Madeira River was sampled at about $\sim 40 \mathrm{~km}$ below the Beni-Mamoré confluence (Mad 19) and again at Porto Velho (Mad 20).

Pure quartz of grain sizes between 125 and 500 $\mu \mathrm{m}$ was selected for ${ }^{10} \mathrm{Be}$ analysis after drying, sieving, magnetic separation and selective leaching with hydrofluoric acid $(5 \%) .{ }^{10} \mathrm{Be}$ was extracted from purified quartz using standard methods (von Blanckenburg et al. 2004); ${ }^{10} \mathrm{Be} /{ }^{9} \mathrm{Be}$ ratios were measured with accelerator mass spectrometry at ETH Zurich relative to a standard with a nominal value of ${ }^{10} \mathrm{Be} /{ }^{9} \mathrm{Be}=95.5 \times 10^{-12}$, which is based on a ${ }^{10} \mathrm{Be}$ half-life of $1.51 \mathrm{Myr}$ (Hofmann et al. 1987) and sample ratios were then corrected as described by as described by Synal et al. (1997). Up to $300 \mu \mathrm{g}$ of ${ }^{9} \mathrm{Be}$ carrier was added to each sample; ${ }^{10} \mathrm{Be} /{ }^{1} \mathrm{Be}$ ratios are given in table 1 . Analytical as well as blank error corrections are described in table 1 . Calculations of production rates, using pixel-based altitudes from $1 \mathrm{~km}$ resolution SRTM-DEM, and attenuation laws including muons were done following Schaller et al. (2002); atmospheric scaling was done 
following Dunai (2000). As a sea level high latitude reference production rate we used a value of $5.53 \mathrm{at} / \mathrm{g}_{(\mathrm{Qz})}$ (Kubik et al. 1998). Published denudation rates from the high Andes of the Andean Beni basin by Safran et al. (2005) were recalculated for comparison with our dataset; we have recalculated their denudation rates for Dunai's atmospheric scaling laws and included nuclide production by muons as suggested by Schaller et al. (2002). A revised dataset, calculated with a revised ${ }^{10} \mathrm{Be}$ half-life (Chmeleff et al., 2010), reduced ${ }^{10} \mathrm{Be} /{ }^{\circ} \mathrm{Be}$ ratios according to Kubik and Christl (2010) to allow for direct comparison with new AMS standards, and newlyrevised lower reference production rates (e.g. Fenton et al., 2011), can be obtained from the author upon request.

COSMOGENIC ${ }^{10} \mathrm{Be}$ NUCLIDE CONCENTRATION RESULTS Nuclide concentrations of ${ }^{10} \mathrm{Be}$ have been measured over distances of $800 \mathrm{~km}$ along the river course at various points from Rurrenabaque to Porto Velho (Fig. 1). ${ }^{10} \mathrm{Be}$ nuclide concentrations for the
Andean Beni trunk stream at Rurrenabaque at the upper Beni basin outlet are $3.8 \pm 0.6 \times 10^{4} \mathrm{at} / \mathrm{g}_{(\mathrm{Oz})}$ (average of $\mathrm{Be}$ 1a and $b$ with one sigma uncertainty, where in this study "a" denotes the 125-250 $\mu \mathrm{m}$ and "b" the 250-500 $\mu \mathrm{m}$ grain size fraction; see Tab. 1). The centerpiece of this study are 12 samples (Be 2 to 17 , including replicates and grain sizes, excluding tributaries), taken along the Beni trunk stream downstream of Rurrenabaque to Cachuela Esperanza. The average nuclide concentration from the 12 trunk stream samples upstream of the Beni-Mamoré confluence is $3.7 \pm 0.5 \times 10^{4} \mathrm{at} / \mathrm{g}_{(\mathrm{Qz})}$ (stating one sigma uncertainty; Tab. 1, Fig. 2). Variability within measured nuclide concentrations is however higher as indicated by a standard deviation of $3.7 \pm 1.6 \times 10^{4} \mathrm{at} / \mathrm{g}_{(\mathrm{Oz})}$.

Tributary input to the Beni is characterized by samples from the rivers Madre de Dios at Miraflores (Md 15a), and the Orthón at Caracoles (Or 16b). The cosmogenic nuclide concentration of the Madre de Dios $\left(2.1 \pm 1.0 \times 10^{4} \mathrm{at} / \mathrm{g}_{(\mathrm{Oz})}\right.$; Tab. 1) is comparable with the Beni at their confluence; the Orthón Rivers

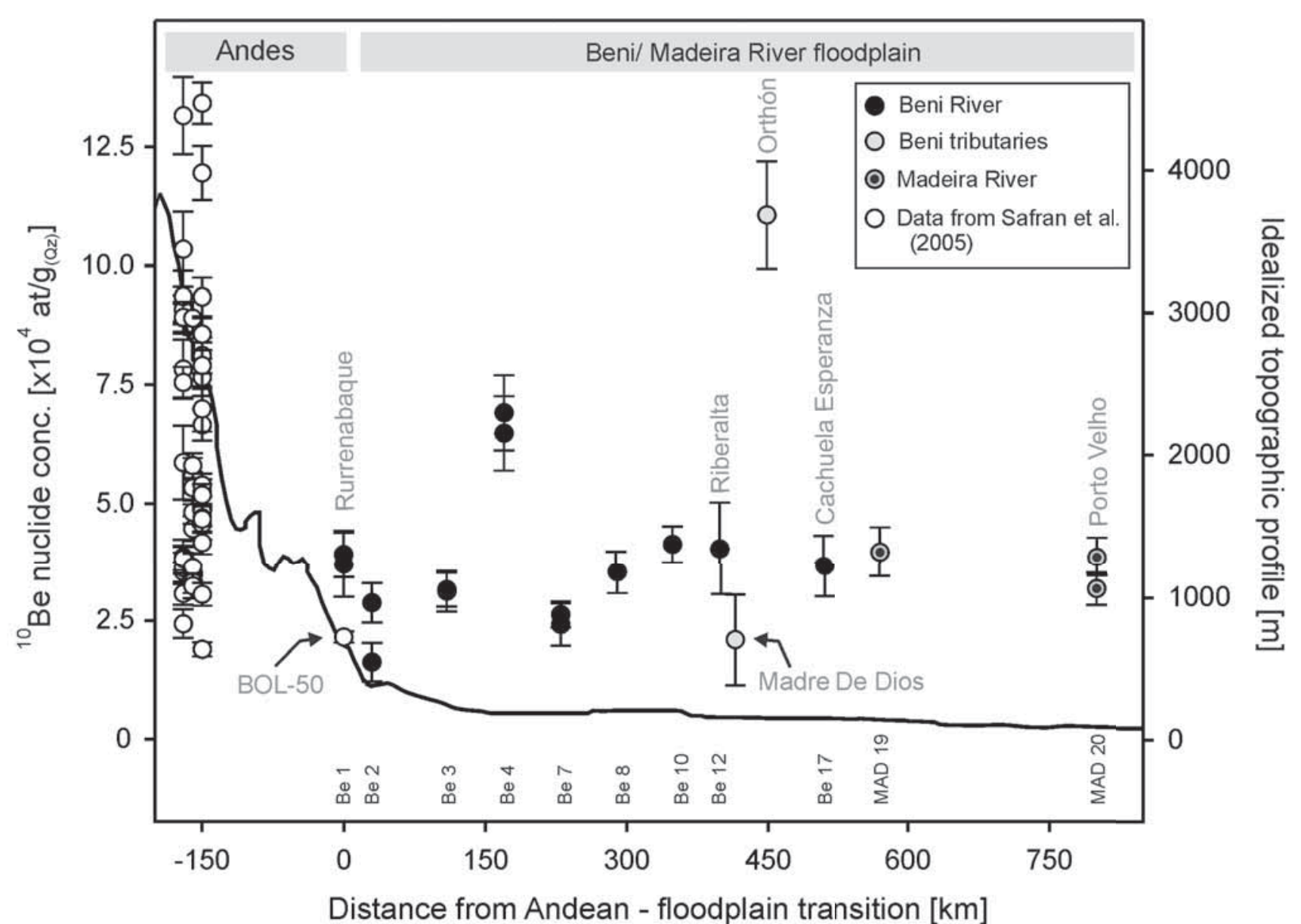

Figure 2 - Cosmogenic nuclide concentration profile for the Beni (black circles) and Madeira River (grey circles with black dot) plotted against distance from transition between Andes and the floodplain at Rurrenabaque (km) with sample IDs (Fig. 1, Tab. 1) given at the bottom. Grey circles denote tributary samples. Right axis gives elevation of idealized topographic profile of the basin $(\mathrm{m})$, which has been projected from several valley-perpendicular profiles into a single plane. Andean nuclide concentrations and nuclide concentration at Rurrenabaque (BOL-50) measured by Safran et al. (2005) are shown as white circles. 


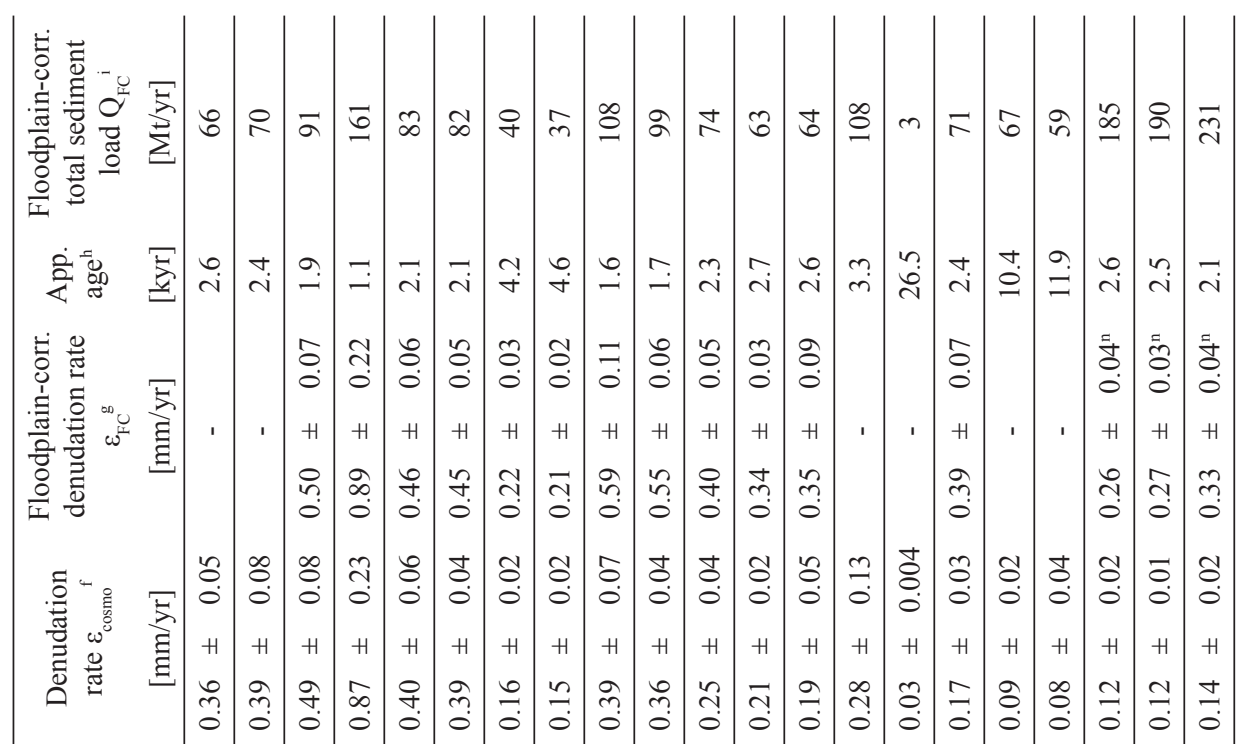

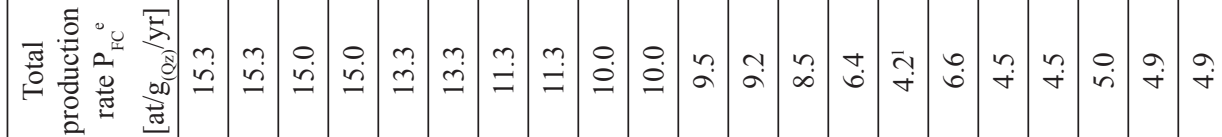
כ. ๓⿴囗十

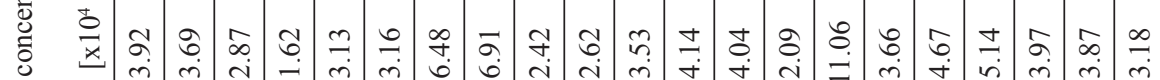

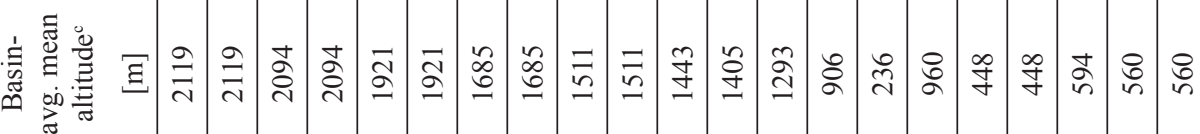

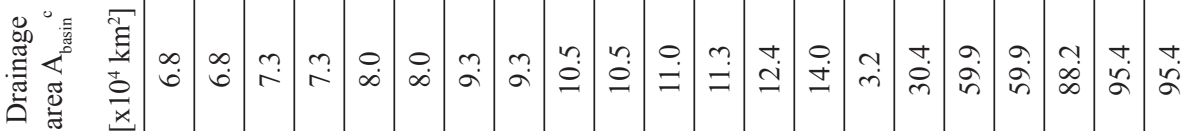

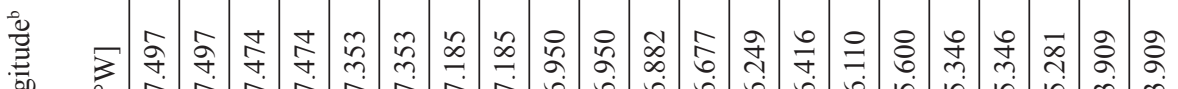
至

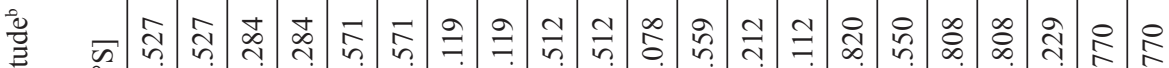

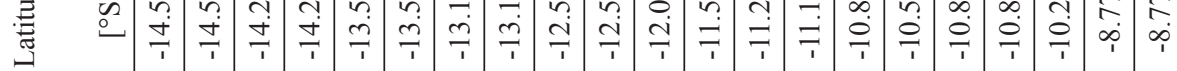

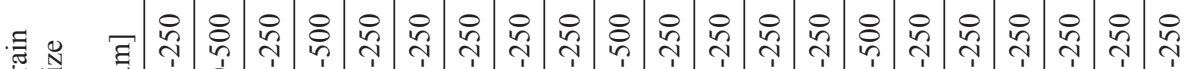

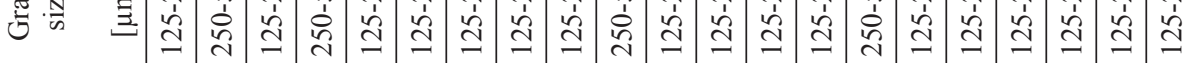

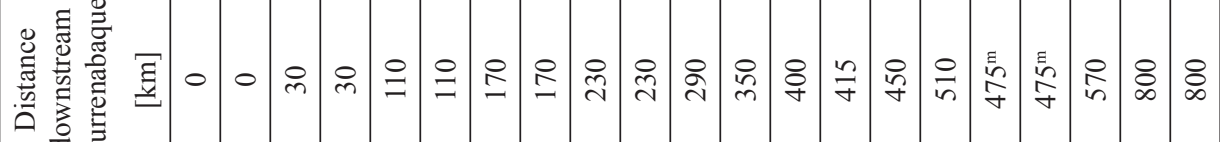
के

ב
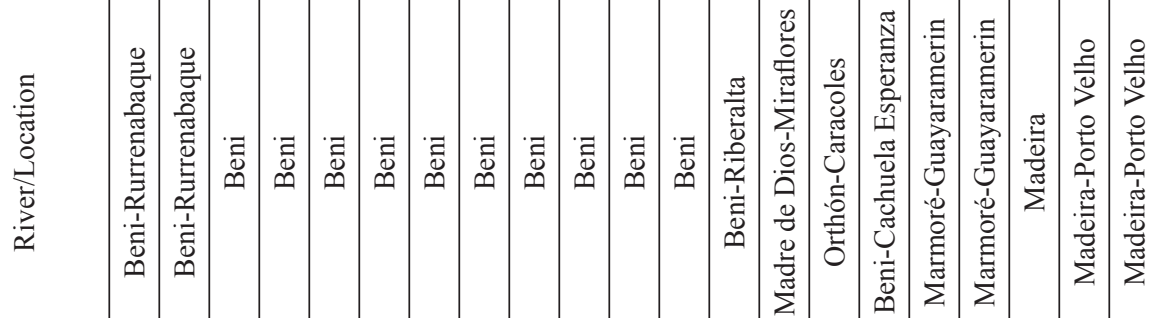

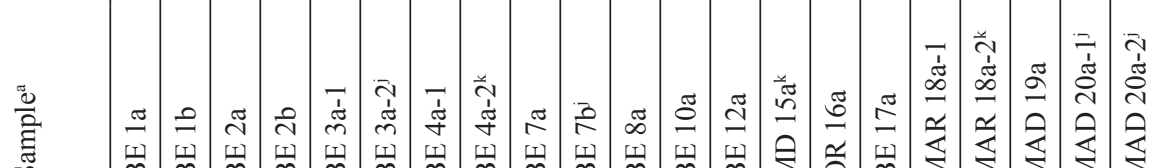

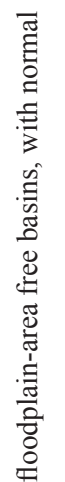
:

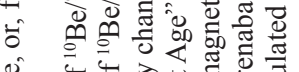

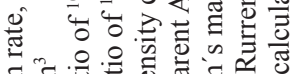

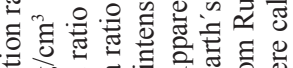
要 क力 ब 讨. 语

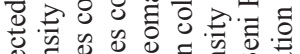
훈

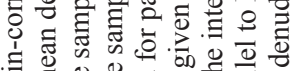

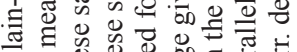
可

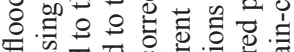

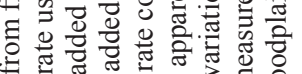

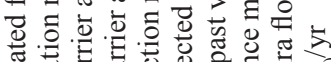

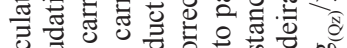

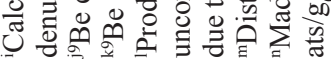

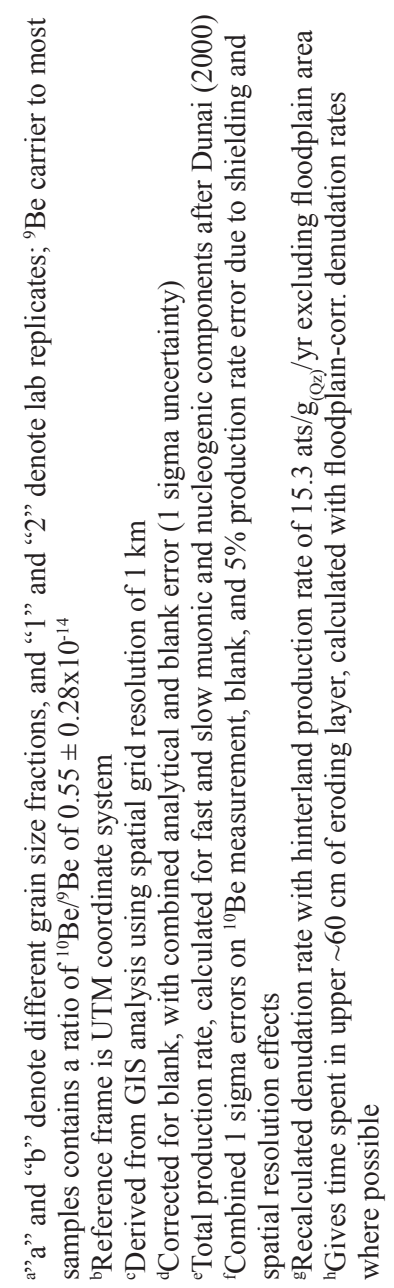


nuclide concentration is with $11.1 \pm 1.1 \times 10^{4} \mathrm{at} / \mathrm{g}_{(\mathrm{Qz})}$ (Tab. 1) clearly distinct from that carried by the Beni River. Sample Mar 18 characterizes the lower Mamoré at Guayaramerin, yielding an average of $4.9 \pm 1.7 \times 10^{4}$ $\mathrm{at} / \mathrm{g}_{(\mathrm{Qz})}$ for the two grain sizes (Tab. 1). This river drains $\sim 60 \%$ old cratonic shield areas (Guaporé River) and $\sim 40 \%$ Andean territory (upper Mamoré River). The Madeira river samples Mad 19a (nuclide concentration is $\left.4.0 \pm 0.5 \times 10^{4} \mathrm{at} / \mathrm{g}_{(\mathrm{OzZ}}\right)$ and $\mathrm{Mad} 20 \mathrm{a}\left(3.5 \pm 0.4 \times 10^{4}\right.$ $\mathrm{at} / \mathrm{g}_{(\mathrm{Oz})} ;$ Tab. 1) integrate over the entire Madeira River basin including the Beni and Mamoré.

\section{COSMOGENIC NUCLIDE BUDGETING OF FLOODPLAIN SEDIMENT TRANSFER IN} THE BENI RIVER The transfer and storage of sediment through a large lowland basin may provide bias on the concentration of cosmogenic nuclides, because cosmogenic nuclide concentrations may be prone to additional irradiation or decay during storage and shielding in floodplain systems. However, we have shown in Section "Cosmogenic ${ }^{10} \mathrm{Be}$ nuclide concentration results" that the Beni floodplain sediment preserves its initial Andean nuclide concentration of $\sim 3.7$ to $3.8 \times 10^{4} \mathrm{at} / \mathrm{g}_{(\mathrm{Qz})}$. In order to elucidate why nuclide concentrations are surprisingly constant during continuous sediment storage and remobilization, we have modeled depth- and time-dependant nuclide production and radioactive decay for the Beni River floodplain (Wittmann \& von Blanckenburg 2009). The Beni River floodplain is a thoroughly investigated system where modern migration rates, recent sediment discharge, and bank erosion rates are well known (Aalto 2002a, Gautier et al. 2007, Guyot et al. 1996). High migration rates account for rapid sediment exchange between the river and the floodplain; Dosseto et al. (2006) have estimated a residence time of sediment in the Beni floodplain between Rurrenabaque and Cachuela Esperanza of 4-6 kyr by using U-series isotopes.

In our dynamic compartment-based model, details of which are published elsewhere (Wittmann \& von Blanckenburg 2009), the river is fed with sediment eroded in the source area that is then being mixed with sediment eroded from the river bank as the river migrates by meandering. In detail, our model assumes erosion of sediment from river cut banks due to lateral bankfull migration, and an admixture of sediment conveyed directly from the previous reach. Sediment deposition is simulated by forming point bars from portions of the mixed material. The model assumes steady-state between river bank erosion and point bar deposition. For the Beni, this assumption has been validated by Aalto et al. (2002b), who have measured the Beni cutbank erosion flux ( $210 \mathrm{Mt} / \mathrm{yr})$ as well as fluxes from point bar re-deposition $(200 \mathrm{Mt} / \mathrm{yr})$. Both are identical to the total annual flux passed on from the sediment-producing areas, the Andes, to the floodplain (210 Mt/yr). Standard model runs were performed using parameters representative of the natural Beni system, such as a starting nuclide concentration $\mathrm{C}_{\text {up }}$ of
$38000 \mathrm{at} / \mathrm{g}_{(\mathrm{Oz})}$ (average from Be 1a and $1 \mathrm{~b}$ ), an ingoing sediment flux of $200 \mathrm{Mt} / \mathrm{yr}$ (average sediment flux at Rurrenabaque), and an average channel depth of $20 \mathrm{~m}$, which estimates floodplain storage depth (Wittmann \& von Blanckenburg, 2009). Within these standard runs, an increase in ${ }^{10} \mathrm{Be}$ nuclide concentrations across the floodplain of only $0.6 \%$, relative to $\mathrm{C}_{\mathrm{up}}$, was detected. We then tested these boundary conditions of the input parameters to changes in climate and erosion. For example, the sediment flux from the Andes was decreased by four orders of magnitude while keeping $\mathrm{C}_{\text {up }}$ constant, as this would be the case during increased aridity in the source areas. A four-fold decrease in channel depth was tested, as during phases of increased precipitation and runoff the river may scour and increase its channel depth. This would result in admixing of less irradiated material to the sediment carried in the main channel. Increasing the estimated average sediment storage time (4-6 kyr) by 10-fold (to 40-60 kyr), a longer-term storage of sediment in the floodplain was tested. The latter test can be seen as an upper-limit test for the successive channel shifting of the Beni River through its floodplain during the Holocene. This 10fold increase in sediment storage time causes ${ }^{10} \mathrm{Be}$ nuclides to accumulate by only $5.8 \%$ over Beni River floodplain distances (relative to $\mathrm{C}_{\text {up }}$ ). All other tests showed even less relative nuclide accumulation. Decay of nuclide concentrations (i.e. resulting in decreased concentrations across the floodplain) was only observed when model runs were performed with shorter-lived nuclides other than ${ }^{10} \mathrm{Be}$, such as in situ- produced ${ }^{14} \mathrm{C}$ (half-life of $5730 \mathrm{yr}$ ), or when storage times of sediment in the floodplain exceeded the half-life of ${ }^{10} \mathrm{Be}$ (newly determined to be $1.39 \mathrm{Myr}$, Chmeleff et al. 2010).

The model outcomes demonstrated here and in more detail in Wittmann \& von Blanckenburg (2009) show that under most conditions encountered in nature, initial nuclide concentrations of the Andean source area are not modified by floodplain processes. Sediment storage times are usually too short when compared to the long half-life of ${ }^{10} \mathrm{Be}$, and floodplain storage depths are too shallow to modify nuclide concentrations from shielding and decay when buried. Overall, the Andean erosion signal is preserved throughout transfer of sediment through the floodplain. These results are supported by a more sophisticated numerical reach-scale theory model by Lauer \& Willenbring (2010), who also conclude that only relatively modest down-channel changes in the concentration of long-lived nuclides occur.

With regard to our observed scatter in nuclide concentrations along the Beni floodplain (see Section "Cosmogenic ${ }^{10} \mathrm{Be}$ nuclide concentration results"), however, we suggest that changes in the erosion rate of the source-areas itself (which would correspond to changing $\mathrm{C}_{\mathrm{up}}$ in our model) cause these variations in nuclide concentrations. Similarly, as the deflection point of the piedmont-lowland transition might have changed in response to basinal uplift, changes in the size of the Andean sediment-providing drainage basin might have comparable effects. 


\section{PREREQUISITES FOR THE CALCULATION} OF DENUDATION RATES IN DEPOSITIONAL BASINS The denudation signal of the sediment source area is preserved by its cosmogenic nuclide concentration, regardless of the duration of temporary storage. This conclusion is drawn from the model presented by Wittmann \& von Blanckenburg (2009) and has validity if the storage is short compared to the half life of the nuclide (see Section "Cosmogenic nuclide budgeting of floodplain sediment transfer in the Beni River"). However, the calculation of a cosmogenic nuclide-derived denudation rate $\left(\varepsilon_{\text {cosmo }}\right)$ that integrates over floodplain area requires scaling of the nuclide production rate to the altitude of the sediment producing area, because within a floodplain, sediment is not actively being produced. We therefore calculated floodplain-corrected cosmogenic nuclide-based denudation rates (termed $\varepsilon_{\mathrm{FC}}$ in the following) (Wittmann $\&$ von Blanckenburg 2009) by defining a "floodplaincorrected" sediment source area $\mathrm{A}_{F C}$ for all basins that contain a portion of floodplain area. $\mathrm{A}_{F C}$ excludes lowland area where sediment is mostly deposited. For the Beni basin, this transition of the sediment-producing regime and that of mostly sediment deposition in the floodplain is located at the city of Rurrenabaque. We then proceeded to calculate an average SRTM pixelbased floodplain-corrected cosmogenic production rate $\left(\mathrm{P}_{F C}\right)$ that is limited to the area contributing sediment in the respective basin (see Tab. 1). Solving Lal's (1991) equation for a uniform floodplain-corrected denudation rate $\varepsilon_{\mathrm{FC}}(\mathrm{mm} / \mathrm{yr})$, one obtains the following simplified equation:

$$
\varepsilon_{F C}=\left(\frac{P_{F C}}{\rho \times C}-\lambda\right) \times \Lambda
$$

where for simplicity the equation is shown with $\mathrm{P}_{F C}$ containing all nucleogenic and muonic production mechanisms. $C$ gives the nuclide concentration $\left(\mathrm{at} / \mathrm{g}_{(\mathrm{Qz}}\right)$ in the sample, $\lambda$ is the decay constant $(1 / \mathrm{yr}), \Lambda$ is a mean cosmic ray attenuation length $\left(\mathrm{g} / \mathrm{cm}^{2}\right)$ including nucleons and muons, and $\rho$ is the density of rock $\left(\mathrm{g} / \mathrm{cm}^{3}\right)$.

Gauging-derived sediment yields in the Beni basin and their treatment For the Beni basin and the Mamoré at Guayaramerin, modern denudation rates from sediment gauging and dissolved element measurements are available for several decades (Tab. 2). In large lowland basins, sediment yields (termed $F_{M}$ in the following, and calculated by taking the measured $\mathrm{Q}_{\mathrm{M}}(\mathrm{t} / \mathrm{yr})$ of a basin divided by $\mathrm{A}_{\text {basin }}\left(\mathrm{km}^{2}\right)$ ) decrease with increasing basin size if no new sediment is added downstream (e.g. Hovius 1998, Milliman and Meade 1983, Milliman \& Syvitski 1992). This effect arises even if no sediment is deposited in the floodplain and the sediment discharge $Q_{M}$ is uniform throughout the floodplain. If the sediment yield is used to calculate denudation rates of the areas actually producing sediment, a correction of this effect is necessary. Thus, published gauging-derived sediment yields $\mathrm{F}_{\mathrm{M}}$ (Tab. 2) were corrected for floodplain area according to:

$$
F_{F C}=\frac{Q_{M}}{A_{F C}}
$$

where $F_{F C}$ is the floodplain-corrected sediment yield of a basin (Tab. 2), and $\mathrm{A}_{\mathrm{FC}}$ is the sedimentproducing area which is determined as described in Section "Prerequisites for the calculation of denudation rates in depositional basins" for cosmogenic nuclide production rates. We term "modern" denudation rates calculated from sediment yields $\varepsilon_{\mathrm{M}}$, and floodplaincorrected modern denudation rates $\varepsilon_{\mathrm{MFC}}$.

The total sediment load that is discharged from the Andes to the Beni floodplain passing Rurrenabaque amounts to $220 \mathrm{Mt} / \mathrm{yr}$ (Guyot et al. 1996) (Tab. 2), which corresponds to a modern denudation rate of 1.18 $\mathrm{mm} / \mathrm{yr}$. At Riberalta (RIB, Fig. 1) gauging station, this flux decreases strongly to $\sim 120 \mathrm{Mt} / \mathrm{yr}$ (corresponds to an $\varepsilon_{\mathrm{MFC}}$ of $0.71 \mathrm{~mm} / \mathrm{yr}$, Tab. 2), indicating net sediment deposition. At Cachuela Esperanza downstream of the Orthón and Madre de Dios confluences, $\varepsilon_{\mathrm{MFC}}$ is with 1.15 $\mathrm{mm} / \mathrm{yr}$ again in the same range as at Rurrenabaque; this increase is attributed to the high sediment input from the Madre de Dios River. At the outlet of the Mamoré floodplain at Guyaramerin, a total sediment flux of $\sim 80$ $\mathrm{Mt} / \mathrm{yr}$ is recorded, which corresponds to a denudation rate $\varepsilon_{\mathrm{MFC}}$ of $0.25 \mathrm{~mm} / \mathrm{yr}$.

\section{COSMOGENIC ${ }^{10}$ Be-DERIVED DENUDATION RATES AND THEIR INTERPRETATION}

Denudation rates of the sediment-producing upper Andean Beni basin Measured cosmogenic ${ }^{10} \mathrm{Be}-$ derived denudation rates $\varepsilon_{\text {cosme }}$ result in an average denudation rate of $0.37 \pm 0.06 \mathrm{~mm} / \mathrm{yr}$ from samples Be 1a and 1b (Tab. 1, Fig. 3) at the transition from the Andes to the floodplain. This denudation rate should average over the entire upper Beni basin, including the high Andes and Piedmont section. At the same location, Safran et al. (2005) have determined a cosmogenic nuclide-based denudation rate of $0.55 \pm 0.03 \mathrm{~mm} / \mathrm{yr}$ (recalculated from sample BOL-50, Safran et al. 2005). The observed difference results from different nuclide concentrations when taking the same production rate for denudation rate calculation and can potentially be attributed to temporal variability of source areas providing sediment. For example, Safran et al. (2005) have sampled in June 1998, at the end of the flood period, while samples for this study have been taken in October 2002, during the low water stage. The higher denudation rate measured at Rurrenabaque by Safran et al. (2005) might be indirectly induced by a stronger ENSO event during the sampled year, producing large landslides in the Piedmont region at elevations below 3,000 m (Blodgett \& Isacks 2007). Our sampling year 2002, was, in terms of the southern oscillation, a normal year. The beginning of 1998 during which Safran et al. sampled was influenced by a strong El Niño phenomenon, and the end of the year was influenced by a moderately strong La Niña (Romero 
et al. 2007). Thus, lower the nuclide concentration measured at Rurrenabaque by Safran et al. (2005) might be indirectly induced by a stronger ENSO event during the sampled year, producing large landslides in the Piedmont region.

In addition to temporal variations, we cannot exclude the possibility of spatial variations in erosion sources in the Bolivian Andes. For example, stream sediment in the upper Beni basin can vary in the mixing proportions of sediment sourced in the high-relief, steeply sloped Andean part and the low-relief Piedmont section. For the Piedmont region, no $\varepsilon_{\text {cosm }}$ data is available. The dataset from Safran et al. (2005) documents the high spatial variability of denudation rates present in the high
Bolivian Andes; the mean denudation rate amounts to $0.36 \mathrm{~mm} / \mathrm{yr}$ with a standard deviation of $0.22 \mathrm{~mm} / \mathrm{yr}$. The flux-weighted mean for this area amounts to 0.43 $\pm 0.03 \mathrm{~mm} / \mathrm{yr}$, which compares reasonably well to our denudation rate measured at Rurrenabaque.

Denudation rates derived from fission-track analyses in the upper Beni basin integrate over long time scales from 5 to $20 \mathrm{Myr}$ and the observed rates are with $0.2-0.6 \mathrm{~mm} / \mathrm{yr}$ (average $\sim 0.3 \mathrm{~mm} / \mathrm{yr}$ ) in the range of cosmogenic nuclide-derived denudation rates (Safran et al. 2006). An exponential increase in exhumation rate at $10-15 \mathrm{Myr}$ from 0.2 to $\sim 0.7 \mathrm{~mm} / \mathrm{yr}$ has also been suggested for this area by Benjamin et al. (1987) and Anders et al. (2002).

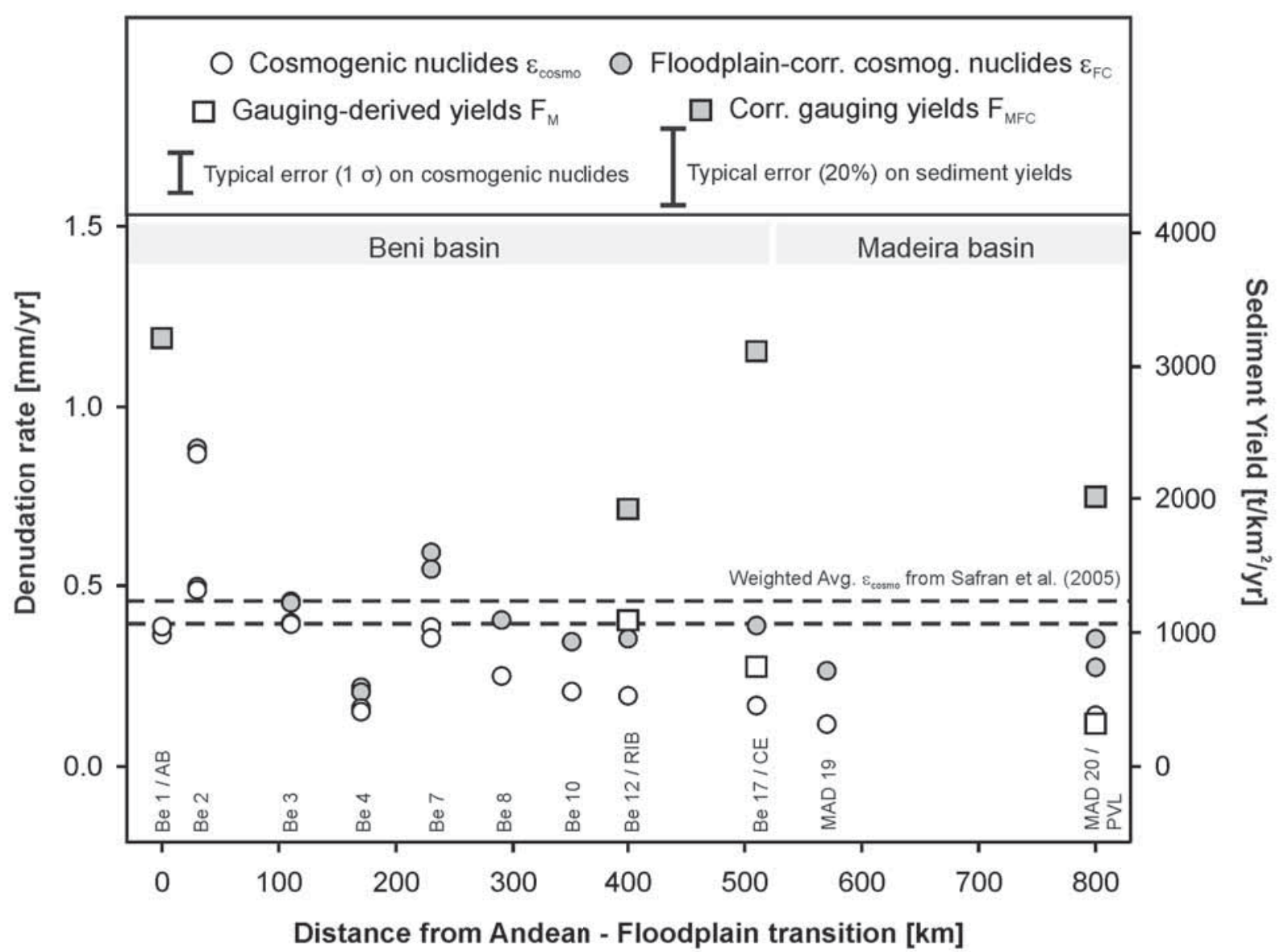

Figure 3 - Basin-averaged denudation rates for the Beni River floodplain, calculated using the production rate relevant to each sampling points' basin hypsometry (white circles; left axis) from Rurrenabaque to Porto Velho. Using a hinterland production rate of $15.3 \mathrm{at} / \mathrm{g}_{(\mathrm{Qz})} / \mathrm{yr}$, the cosmogenic denudation rates of the Beni River floodplain were recalculated according to Eq. 1 (grey circles). The rivers Madre de Dios, Orthón, and Mamoré (samples Md 15a, Or16b, and Mar 18) are not included, because their basins integrate over different Andean source areas and thus have different starting production rates. Denudation rates for the Madeira river samples (Mad 19a and Mad $20 \mathrm{at} 570 \mathrm{~km}$ and $800 \mathrm{~km}$, respectively) have been calculated using a production rate of $12.9 \mathrm{at} / \mathrm{g}_{\left(\mathrm{Q}_{z}\right.} / \mathrm{yr}$. White squares show sediment yield data from gauging stations (right axis; from Guyot et al. 1996), which also have been recalculated with the surface area of the sediment-providing area of $6.8 \times 10^{4} \mathrm{~km}^{2}$ at Rurrenabaque according to Eq. 2 (grey squares), except at PVL on the Madeira River, where the total Andean area is $26 \times 10^{4} \mathrm{~km}^{2}$. Sediment yield was calculated from erosion rates using a density of $2.7 \mathrm{~g} / \mathrm{cm}^{3}$ and thus, right and left axis scale linearly. Typical error bars for both methods are also given. Vertical dashed lines denote the flux-weighted Andean mean from Safran et al. (2005). For abbreviations, see figure 1. 


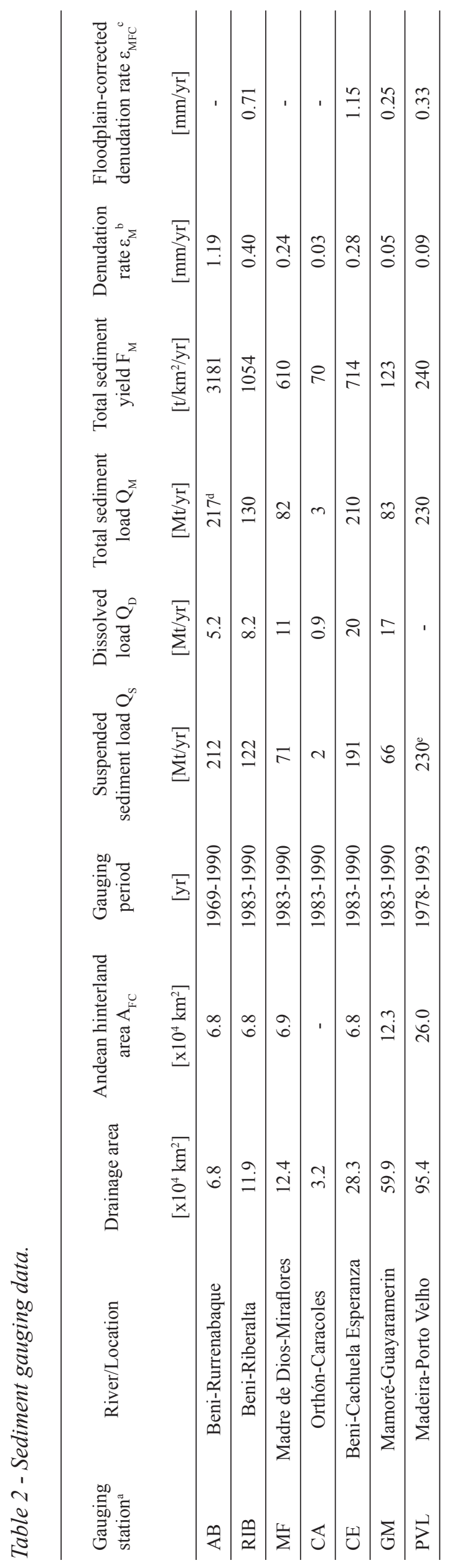

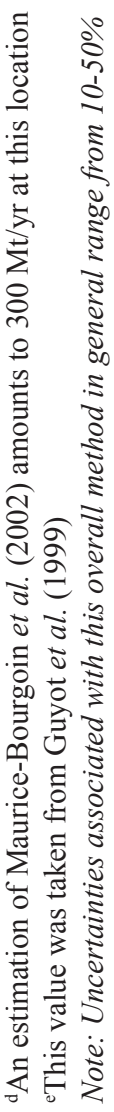

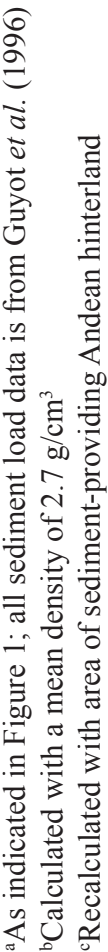

Denudation rates of the Beni River floodplain From our ${ }^{10} \mathrm{Be}$ nuclide concentrations obtained in Section "Cosmogenic ${ }^{10} \mathrm{Be}$ nuclide concentrations results", we recalculated the denudation rates for the Beni River floodplain according to Section "Prerequisites for the calculation of denudation rates in depositional basins" to include the sediment-producing areas only $\left(\varepsilon_{\mathrm{FC}}\right.$, see Eq. 1) following Wittmann \& von Blanckenburg (2009). Results from this recalculation give an average floodplain denudation rate $\varepsilon_{\mathrm{FC}}$ of $0.45 \pm 0.06 \mathrm{~mm} / \mathrm{yr}$ (all uncertainties one sigma) that is very similar to our Andean denudation rate estimate at Rurrenabaque $(0.37 \pm 0.06 \mathrm{~mm} / \mathrm{yr})$, and to the average rate of $0.55 \pm 0.03 \mathrm{~mm} / \mathrm{yr}$ at Rurrenabaque determined by Safran et al. (2005).

The denudation rate for the Madeira basin, which includes the Beni and Mamoré basins, amounts to 0.28 $\pm 0.04 \mathrm{~mm} / \mathrm{yr}$ from samples Mad 19 and Mad 20 ( $\mathrm{n}=$ 3 ). This rate is lower than average Andean rate derived from the mean Beni denudation rate at Rurrenabaque $(0.37 \pm 0.06 \mathrm{~mm} / \mathrm{yr})$. This decrease is probably caused by high-nuclide concentration input from the Guaporé basin, which is demonstrated by higher mean nuclide concentrations for samples Mar 18 (see Tab. 1). The Guaporé River mostly drains the Brazilian shield, an area of high long-term geomorphic stability featuring old Precambrian rocks that evidently erode at very slow rates (Wittmann et al. 2011).

\section{DISCUSSION}

Cosmogenic nuclide-derived denudation rates compared to published gauging-derived rates Sediment-gauging derived denudation rates $\left(\varepsilon_{\mathrm{MFC}}\right)$ for the Beni floodplain are with a mean rate of $\sim 1 \mathrm{~mm} / \mathrm{yr}$ (Tab. 2) significantly higher than the mean cosmogenic nuclide-derived rate $\left(\varepsilon_{\mathrm{FC}}=0.45 \mathrm{~mm} / \mathrm{yr}\right)$. This difference is probably due to the different integration time scales of both methods. Our cosmogenic nuclide measurements record the time-integrated signal of denudation for the last $2.4 \mathrm{kyr}$ in the Beni, whereas sediment gauging data integrates over the gauging period, which is typically $\sim 10 \mathrm{yr}$ (see Tab. 2). An increase in modern denudation rates can be attributed to changes in land use (Vanacker et al. 2007) or climate (e.g. Cross et al. 2000) in the sediment-providing area. For example, the midHolocene period in the Central Andes is characterized by aridity (see Section "Geology, geomorphology, and climate"), with levels of Lake Titicaca being $\sim 100 \mathrm{~m}$ lower than today. The final termination of the arid phase is being discussed, but occurred at the latest around 1.5 kyr (Tapia et al. 2003). In this case our new cosmogenic nuclide-derived denudation rates would integrate over a drier climatic phase than today, which could result in the offset between higher modern and lower long-term erosion rates.

The temporal and spatial scales in denudation and their extension to floodplain settings A summary of all cosmogenic nuclide-derived denudation rate data for specific regions in the Madeira basin, also including 
the Mamoré basin, is given in figure 4 (Wittmann et al. 2009). In the following, we will discuss the significance of the observed erosion patterns in terms of more general issues, e.g. (1) temporal uniformity in denudation, and (2) the observation that the spatial scale of cosmogenicderived denudation meters from the source area may be extended to depositional floodplain settings. (1) Long-term denudation rates derived from fission-track analyses are very similar to the cosmogenic nuclidederived denudation rates in the upper Beni basin. This finding is surprising, given that the Holocene period over which cosmogenic nuclides record denudation is not necessarily representative for the Quaternary and Pliocene climate over which fission tracks operate. Yet this observation has been made elsewhere (Kirchner et al. 2001, Matmon et al. 2003, Wittmann et al. 2007) for very different settings in terms of climatic and tectonic boundary conditions. (2) Denudation rates recorded by cosmogenic nuclides are subjected to strong spatial scatter in the high Andes of the Beni basin (see Section "Denudation rates of the sediment-producing upper Andean Beni basin"). This scatter is only to some extent preserved in lowland nuclide concentrations; the overall variability in lowland nuclide concentrations is much lower than the variability observed in the source area (Fig. 5). With increasing basin size, this observed scatter seems to be averaged out, and average denudation rates are similar for all basin sizes. For Andean basins $<1,000 \mathrm{~km}^{2}$, flux-weighted denudation rates average $0.47 \pm 0.03 \mathrm{~mm} / \mathrm{yr}$ and to $0.42 \pm 0.03 \mathrm{~mm} /$ $\mathrm{yr}$ for basins between $1,000-11,000 \mathrm{~km}^{2}$, respectively. Floodplain basins $>70,000$ to $\sim 300,000 \mathrm{~km}^{2}$ average

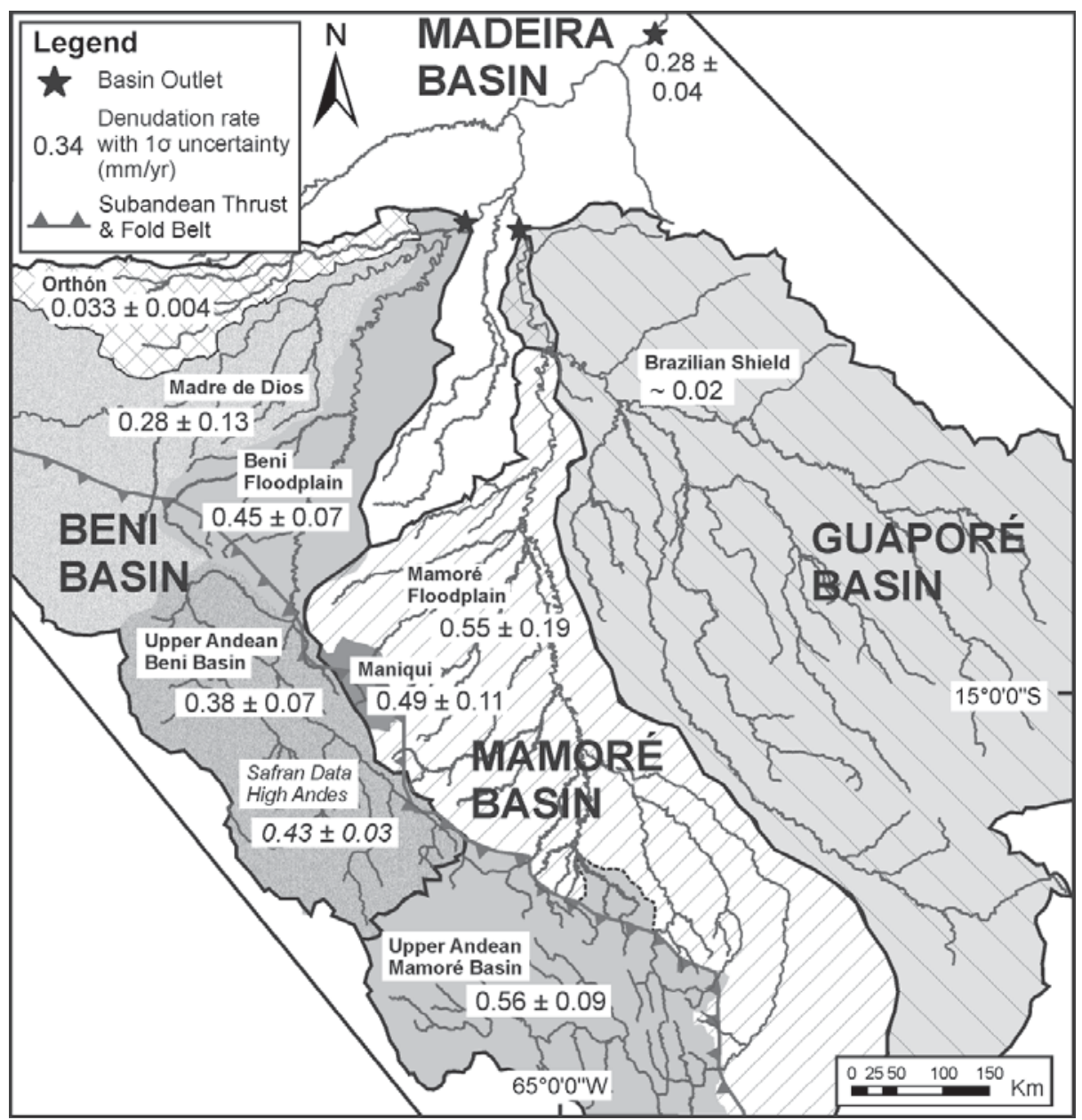

Figure 4 - Cosmogenic nuclide-derived denudation rates ( $\mathrm{mm} / \mathrm{yr}$ ) for tributaries of the Madeira basin including the Beni, Mamoré and Guaporé basins (Wittmann et al. 2009), of which their outlets are marked by black stars. The Beni basin is subdivided into its major tributaries of Orthón and Madre de Dios as well as the upper Andean part of the basin, for which an average denudation rate from sample Be 1 is given as well as the weighted mean recalculated from Safran et al. (2005). The Andean Mamoré basin includes the small Maniqui catchment and more southern Andean Mamoré samples of the Grande, Pirai, Ichilo, and Chaparé Rivers. The floodplain part of the Ichilo basin is indicated by the dashed line. An average denudation rate for the Brazilian Shield ( 0.02 mm/ yr) has been taken from Wittmann (2008). Figure reprinted from "From source to sink: Preserving the cosmogenic ${ }^{10}$ Be-derived denudation rate signal of the Bolivian Andes in sediment of the Beni and Mamoré foreland Basins", Vol. 288 by Wittmann et al. (2009), page 472, with permission from Elsevier. 


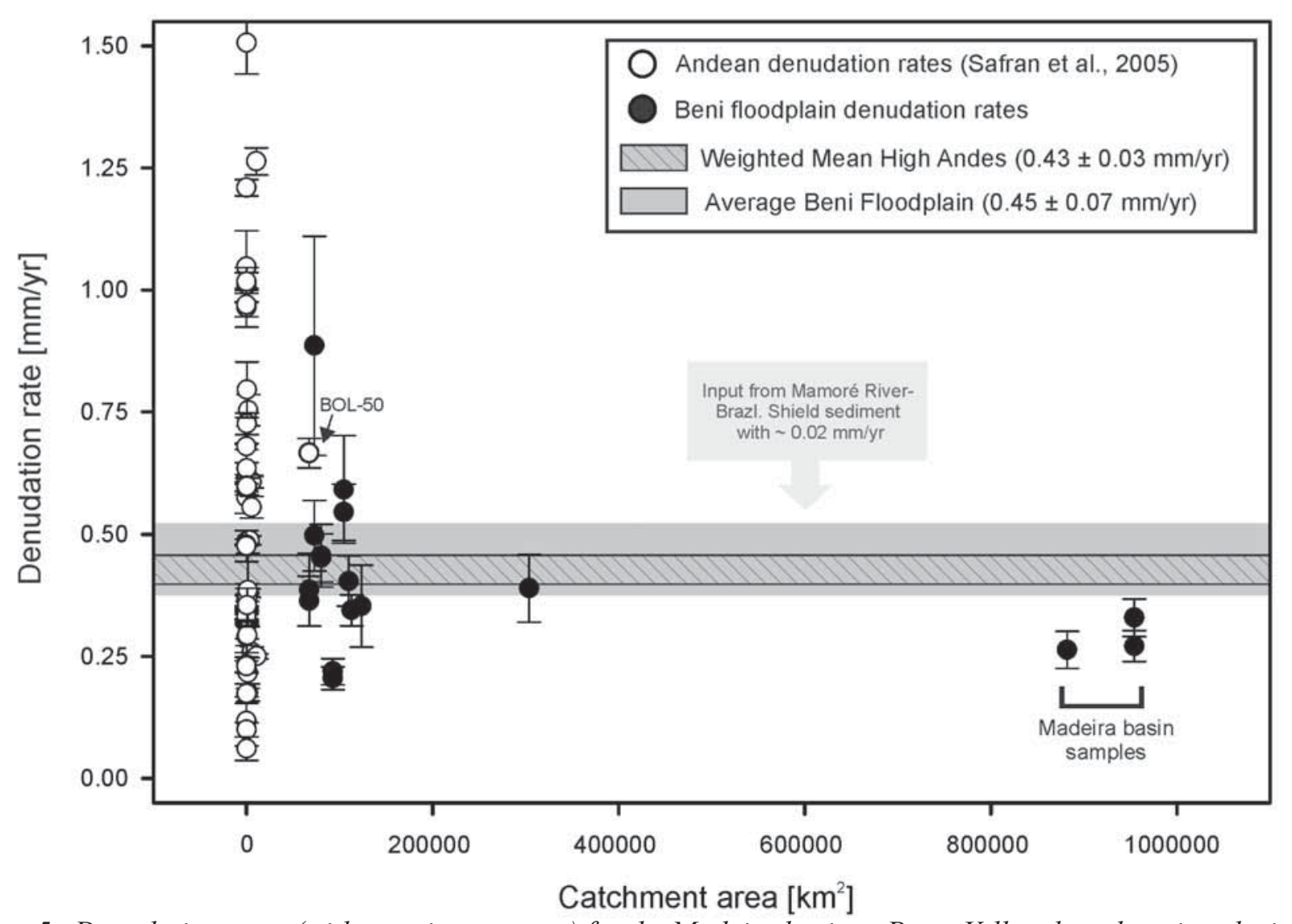

Figure 5 - Denudation rates (with one sigma errors) for the Madeira basin at Porto Velho plotted against drainage area. Andean cosmogenic nuclide data is recalculated from Safran et al. (2005). Floodplain rates are corrected for decrease in production rate across low-elevation floodplain areas according to Eq. 1. The data shows that with increasing basin area, the spread in denudation rate decreases, and that the cosmogenic sample taken at $1.000 .000 \mathrm{~km}^{2}$ (Porto Velho) is similar to the Andean mean rate from Safran et al. (2005). The difference to the Andean average is in this case attributed to sediment input high in nuclide concentration from the slowly eroding parts of the Guaporé basin. Figure reprinted from "From source to sink: Preserving the cosmogenic ${ }^{10} B e$-derived denudation rate signal of the Bolivian Andes in sediment of the Beni and Mamoré foreland Basins", Vol. 288 by Wittmann et al. (2009), page 473, with permission from Elsevier.

to $0.45 \pm 0.06 \mathrm{~mm} / \mathrm{yr}$ ( $\varepsilon_{\mathrm{FC}}$, samples Be 2 to 17 ). This signal is again similar to the long-term erosional signal of $\sim 0.3 \mathrm{~mm} / \mathrm{yr}$ from fission tracks. An explanation for this uniformity may lie in the ability of the floodplain to buffer against changing sediment supply discharged from the source area (Métivier \& Gaudemer 1999). Continuous storage and remobilization of alluvium via lateral channel migration in the floodplain apparently damps effects from changing sediment supply caused by climatic or tectonic perturbations.

CONCLUSIONS This study shows that denudation rates measured from cosmogenic nuclide concentrations in the floodplain of the Beni basin (Bolivia) are, within a variability expected of high-relief areas that tend to erode stochastically, identical to those obtained from the sediment-providing Bolivian Andes. Cosmogenic nuclide concentrations in the floodplain are not altered by storage of sediment that is longer than the integration times of the cosmogenic nuclide method. In addition, the large variability in Andean denudation rates does not transfer to the floodplain setting where we notice very small variability in cosmogenic nuclide-derived denudation rates. This indicates that denudation rates converge to a spatially-averaged erosion signal in the lowlands. When compared to long-term estimates of erosion, cosmogenic nuclide-derived denudation rates in the floodplain resemble those from Andean fission track analysis. These findings allow the suggestion that cosmogenic nuclides are the method of choice for tracing denudation rate signals over large floodplain distances. Denudation rates of the sediment-producing areas are being conserved as spatially and temporally averaged signals, and short-term spatial or temporal changes are dampened-out. In such large depositional basins, the denudation signal from the sediment-providing area is not only preserved, but also will a sample collected at any point along the river course from within the active floodplain channel yield an average denudation rate of the source area. 
Acknowledgements The authors want to thank Liz Safran for providing her data and for numerous discussions. This work was supported by Deutsche Forschungs gemeinschaft grant Bl 562/2-2.

\section{References}

Aalto R. 2002a. Geomorphic form and process of sediment flux within an active orogen: Denudation of the Bolivian Andes and sediment conveyance across the Beni foreland. Ph.D. Thesis, University of Washington, Washington, $365 \mathrm{p}$.

Aalto R., Dunne T., Nittrouer C., Maurice-Bourgoin L., Montgomery D. 2002b. Fluvial transport of sediment across a pristine tropical foreland basin: Channel-flood plain interaction and episodic flood plain deposition. In: Dyer F.J., Thoms M.C., Olley J.M. (eds.) The Structure, Function and Management Implications of Fluvial Sedimentary Systems. Alice Springs, IAHS, p. 339-344.

Abbott M.B., Wolfe B.B., Wolfe A.P., Seltzer G.O., Aravena R., Mark B.G., Polissar P.J., Rodbell D.T., Rowe H.D., Vuille M. 2003. Holocene paleohydrology and glacial history of the central Andes using multiproxy lake sediment studies. Palaeogeography, Palaeoclimatology, Palaeoecology, 194(1-3):123-138.

Anders M.H., Gregory-Wodzicki K.M., Spiegelman M. 2002. A critical evaluation of late tertiary accelerated uplift rates for the Eastern Cordillera, central Andes of Bolivia. Journal of Geology, 110(1):89-100.

Benjamin M.T., Johnson N.M., Naeser C.W. 1987. Recent rapid uplift in the Bolivian Andes: Evidence from fission-track dating. Geology, 15(7):680-683.

Bierman P. \& Steig E.J. 1996. Estimating rates of denudation using cosmogenic isotope abundances in sediment. Earth Surface Processes and Landforms, 21(2):125-139.

Bierman P.R. \& Nichols K.K. 2004. Rock to sediment - Slope to sea with Be-10 - Rates of landscape change. Annual Review of Earth and Planetary Sciences, 32:215-255.

Blodgett T.A. \& Isacks B.L. 2007. Landslide erosion rate in the Eastern Cordillera of Northern Bolivia. Earth Interactions, 11:1-30.

Chmeleff J., von Blanckenburg F., Kossert K., Jakob D. 2010. Determination of the ${ }^{10} \mathrm{Be}$ half-life by multicollector ICP-MS and liquid scintillation counting. Nuclear Instruments and Methods in Physics Research, Section B: Beam Interactions with Materials and Atoms, 268(2):192-199 [doi: 10.1016/j.nimb.2009.09.012]

Cross S.L., Baker P.A., Seltzer G.O., Fritz S.C., Dunbar R.B. 2000. A new estimate of the Holocene lowstand level of Lake Titicaca, central Andes, and implications for tropical palaeohydrology. Holocene, 10(1):21-32.

Dosseto A., Bourdon B., Gaillardet J., Maurice-Bourgoin L., Allegre C.J. 2006. Weathering and transport of sediments in the Bolivian Andes: Time constraints from uranium-series isotopes. Earth and Planetary Science Letters, 248(3-4):759-771.

Dumont J.F. 1996. Neotectonics of the subandes-Brazilian craton boundary using geomorphological data : the Maranon and Beni basins. Tectonophysics, 259:137-151.

Dunai T.J. 2000. Scaling factors for production rates of in situ produced cosmogenic nuclides: a critical reevaluation. Earth and Planetary Science Letters, 176(1):157-169.
Espurt N., Baby P., Brusset S., Roddaz M., Hermoza W., Regard V., Antoine P.O., Salas-Gismondi R., Bolaños R. 2007. How does the Nazca Ridge subduction influence the modern Amazonian foreland basin? Geology, 35(6):515-518 [doi: 10.1130/G23237A.1].

Fenton C.R., Hermanns R.L., Blikra L.H., Kubik P.W., Bryant C., Niedermann S., Meixner A., Goethals M.M. 2011. Regional ${ }^{10} \mathrm{Be}$ production rate calibration for the past $12 \mathrm{ka}$ deduced from the radiocarbon-dated Grøtlandsura and Russenes rock avalanches at $69^{\circ} \mathrm{N}$, Norway. Quaternary Geochronology, 6:437-452.

Gautier E., Brunstein D., Vauchel P., Roulet M., Fuertes O., Guyot J.L., Darozzes J., Bourrel L. 2007. Temporal relations between meander deformation, water discharge and sediment fluxes in the floodplain of the Rio Beni (Bolivian Amazonia). Earth Surface Processes and Landforms, 32(2):230-248.

Granger D.E. \& Riebe C.S. 2007. Cosmogenic nuclides in weathering and erosion. In: Drever J.I. (ed.) Surface and Ground Water, Weathering, and Soils - Treatise on Geochemistry. London, Elsevier, p. 2-40.

Guyot J.L., Filizola N., Quintanilla J., Cortez J. 1996. Dissolved solids and suspended sediment yields in the Rio Madeira basin, from the Bolivian Andes to the Amazon. In: Walling D.E. \& Webb B.W. (eds.) Erosion and Sediment yield: Global and Regional Perspectives. Exeter, IAHS, p. 55-63.

Guyot J.L., Jouanneau J.M., Wasson J.G. 1999. Characterisation of river bed and suspended sediments in the Rio Madeira drainage basin (Bolivian Amazonia). Journal of South American Earth Sciences, 12(4):401-410.

Hofmann H.J., Beer J., Bonani G., von Gunten H.R., Raman S., Suter M., Walker R.L., Wölfli W., Zimmermann D. 1987. ${ }^{10} \mathrm{Be}$ : Half-life and AMS-standards. Nuclear Instruments \& Methods in Physics Research Section B - Beam Interactions with Materials and Atoms, 29(12):32-36 [doi: 10.1016/0168-583X(87)90198-4]

Hovius N. (ed.) 1998. Controls on sediment supply by large rivers. In: Shanley K.W., McCabe P.J. (eds.) Relative role of eustasy, climate, and tectonism in continental rocks. Tulsa, Society for Sedimentary Geology Special Publication, p. 3-16 [doi: 10.2110/pec.98.59.0002].

Kirchner J.W., Finkel R.C., Riebe C.S., Granger D.E., Clayton J.L., King J.G., Megahan W.F. 2001. Mountain erosion over $10 \mathrm{yr}, 10 \mathrm{k} . \mathrm{y}$. , and $10 \mathrm{~m} . \mathrm{y}$. time scales. Geology, 29(7):591-594.

Kubik P.W., Ivy-Ochs S., Masarik J., Frank M., Schluchter C. 1998. Be-10 and Al-26 production rates deduced from an instantaneous event within the dendro-calibration curve, the landslide of Kofels, Oetz Valley, Austria. Earth and Planetary Science Letters, 161(1-4):231-241.

Kubik P.W. \& Christl M. 2010. ${ }^{10} \mathrm{Be}$ and ${ }^{26} \mathrm{Al}$ measurements at the Zurich $6 \mathrm{MV}$ Tandem AMS facility. Nuclear Instruments and Methods in Physics Research Section B: Beam Interactions with Materials and Atoms, 268(78):880-883. 
Lal D. 1991. Cosmic ray labeling of erosion surfaces: in situ nuclide production rates and erosion models. Earth and Planetary Science Letters, 104(2-4):424-439.

Latrubesse E.M. 2008. Patterns of anabranching channels: The ultimate end-member adjustment of mega rivers. Geomorphology, 101(1-2):130-145.

Latrubesse E.M., Stevaux J.C., Sinha R. 2005. Tropical rivers. Geomorphology, 70(3-4):187-206.

Lauer J.W., Willenbring J.K. 2010. Steady-state reach-scale theory for radioactive tracer concentration in a simple channel/floodplain system. J. Geophys. Res. Earth Surface, 115:F04018.

Matmon A., Bierman P.R., Larsen J., Southworth S., Pavich M., Caffee M. 2003. Temporally and spatially uniform rates of erosion in the southern Appalachian Great Smoky Mountains. Geology, 31(2):155-158.

Maurice-Bourgoin L., Aalto R., Guyot J. 2002. Sedimentassociated mercury distribution within a major Amazon tributary: Century-scale contamination history and importance of flood plain accumulation. In: Dyer F.J., Thoms M.C., Olley J.M. (eds.) The Structure, Function and Management Implications of Fluvial Sedimentary Systems. Alice Springs, IAHS, p. 161-168.

Métivier F. \& Gaudemer Y. 1999. Stability of output fluxes of large rivers in South and East Asia during the last 2 million years: implications on floodplain processes. Basin Research, 11(4):293-303.

Milliman J. \& Meade R.H. 1983. World-wide delivery of river sediment to the oceans. Journal of Geology, 91:121.

Milliman J.D. \& Syvitski J.P.M., 1992. Geomorphic tectonic control of sediment discharge to the ocean- The importance of small mountainous rivers. Journal of Geology, 100(5):525-544.

Nichols K.K., Bierman P.R., Caffee M., Finkel R., Larsen J. 2005. Cosmogenically enabled sediment budgeting. Geology, 33(2):133-136.

Nichols K.K., Bierman P.R., Hooke R.L., Clapp E.M., Caffee M. 2002. Quantifying sediment transport on desert piedmonts using ${ }^{10} \mathrm{Be}$ and ${ }^{26} \mathrm{Al}$. Geomorphology, 45(1-2):105-125.

Plafker G. 1964. Oriented Lakes and Lineaments of Northeastern Bolivia. Geological Society of America Bulletin, 75(6):503-522.

Romero C., Baigorria G., Stroosnijder L. 2007. Changes of erosive rainfall for El Niño and La Niña years in the northern Andean highlands of Peru. Climatic Change, 85:343-356.

Rowe H., Dunbar R., Mucciarone D., Seltzer G., Baker P., Fritz S. 2002. Insolation, moisture balance and climate change on the South American Altiplano since the Last Glacial Maximum. Climatic Change, 52:175-199.

Safran E.B., Bierman P.R., Aalto R., Dunne T., Whipple K.X., Caffee M. 2005. Erosion rates driven by channel network incision in the Bolivian Andes. Earth Surface Processes and Landforms, 30:1007-1024 [doi: 10.1002/ esp.1259].

Safran E.B., Blythe A., Dunne T. 2006. Spatially variable exhumation rates in orogenic belts: An Andean example. Journal of Geology, 114(6):665-681.
Schaller M., von Blanckenburg F., Veldkamp A., Tebbens L.A., Hovius N., Kubik P.W. 2002. A 30000 yr record of erosion rates from cosmogenic Be-10 in Middle European river terraces. Earth and Planetary Science Letters, 204(12):307-320 [doi: 10.1016/S0012-821X(02)00951-2].

Synal H.A., Bonani G., Döbeli M., Ender R.M., Gartenmann P., Kubik P.W., Schnabel Ch., Suter M. 1997. Status report of the PSI/ETH AMS facility. Nuclear Instruments \& Methods in Physics Research Section B - Beam Interactions with Materials and Atoms, 123(1-4):62-68 [doi: 10.1016/S0168-583X(96)00608-8].

Tapia P.M., Fritz S.C., Baker P.A., Seltzer G.O., Dunbar R.B. 2003. A Late Quaternary diatom record of tropical climatic history from Lake Titicaca (Peru and Bolivia). Palaeogeography, Palaeoclimatology, Palaeoecology, 194(1-3):139-164.

Vanacker V., von Blanckenburg F., Govers G., Molina A., Poesen J., Deckers J., Kubik P. 2007. Restoring dense vegetation can slow mountain erosion to near natural benchmark levels. Geology, 35(4):303-306 [doi: 10.1130/G23109A.1].

von Blanckenburg F. 2005. The control mechanisms of erosion and weathering at basin scale from cosmogenic nuclides in river sediment. Earth and Planetary Science Letters, 237(3-4):462-479.

von Blanckenburg F., Hewawasam T., Kubik P.W. 2004. Cosmogenic nuclide evidence for low weathering and denudation in the wet, tropical highlands of Sri Lanka. J. Geophys. Res., 109(F03008):1-22 [doi: 10.1029/2003JF000049].

Wittmann H. \& von Blanckenburg F. 2009. Cosmogenic nuclide budgeting of floodplain sediment transfer. Geomorphology, 109(3-4):246-256.

Wittmann H., von Blanckenburg F., Guyot J.L., Maurice L., Kubik P.W. 2009. From source to sink: Preserving the cosmogenic $10 \mathrm{Be}$-derived denudation rate signal of the Bolivian Andes in sediment of the Beni and Mamoré foreland basins. Earth and Planetary Science Letters, 288(3-4):463-474.

Wittmann H. 2008. New applications to in situ-produced cosmogenic nuclides in river sediment: High mountain belt denudation in the Swiss Alps and Bolivian Andes and sediment transfer and storage in the Amazon basin. Ph.D. Thesis, University of Hannover, Hannover, Hannover, $178 \mathrm{p}$.

Wittmann H., von Blanckenburg F., Kruesmann T., Norton K.P., Kubik P.W. 2007. Relation between rock uplift and denudation from cosmogenic nuclides in river sediment in the Central Alps of Switzerland. J. Geophys. Res., 112(F04010):1-20. [doi: 10.1029/2006JF000729].

Wittmann H., von Blanckenburg F., Maurice L., Guyot J.L., Filizola N., Kubik P.W. 2011. Sediment production and delivery in the Amazon River basin quantified by in situproduced cosmogenic nuclides and recent river loads. Geological Society of America Bulletin, 123(5-6):934950 [doi: 10.1130/B30317.1].

Manuscrito ID 17890 Submetido em 30 de junho de 2010 Aceito em 21 de dezembro de 2011 